\title{
Krystyna Walton: trauma rehabilitation specialist
}

Krystyna Walton started her clinical career in rheumatology before moving into neurorehabilitation and leading on major trauma rehabilitation.

\author{
Kathy Oxtoby \\ London, UK
}

\section{Choosing medicine}

I was 15 when I decided on a career in medicine. My chemistry teacher thought it would be a good choice because I was good at sciences. Until then I hadn't even considered going to university-my parents were refugees from Poland and Belarus, they were working class, not particularly well educated, and could read but couldn't write in English.

\section{Dealing with difficulty}

I became interested in rheumatology as a student. I chose it as my elective because at that time it wasn't covered in any detail in the curriculum and I wanted to know about how patients coped with disabilities and long term conditions. It was the complexity of the specialty that appealed to me. Every patient and their family deals with disabilities differently, so every situation is unique.

\section{Developing specialty}

In 1988, I became a consultant in neurorehabilitation at what was formerly the Rochdale Healthcare NHS Trust, which then became the Pennine Acute Hospitals NHS Trust (now part of the new Northern Care Alliance NHS Group). The specialty was in the process of development, and the challenge of developing something new attracted me.

\section{Neurorehabilitation}

That year I set up a neurorehabilitation unit in Rochdale, one of the few of its kind in the country. I found neurorehabilitation more rewarding than rheumatology and thought that I could be of more benefit to patients with brain injuries, or progressive neurological conditions, because there was a need for advocacy to ensure that they got the right services for them.

\section{Teamworking}

Neurorehabilitation needs you to form relationships with colleagues in other specialties in and outside medicine, including joint working with social services and community services. It's very varied, every day is different, and you feel you can make a difference to people's lives.

\section{Managing trauma}

Over time I've become more involved in developing and managing services, such as leading on rehabilitation following major trauma for Greater Manchester since 2012. A year later I became director of Greater Manchester major trauma rehabilitation, which involves developing non-specialist rehabilitation for people who have sustained significant injuries.

\section{Sharing knowledge}

I was the first chair of the specialty training committee in rehabilitation medicine in the North Western Deanery. We started with two trainees but by the time I finished my two year post as training programme director in 2016 we had nine training slots. I have great enthusiasm for the specialty and like to share its complexity with young doctors who have been attracted to rehabilitation medicine. Teaching also makes you think more widely so you don't become stale.

\section{Career highlight}

Until 1998 I had no aspirations beyond managing a rehabilitation unit in a district general hospital. Then Raymond Tallis, who was leading on reconfiguration of Greater Manchester neurosciences services, asked me to help develop the first model in Greater Manchester that integrated neurorehabilitation with neurosciences - a project that changed the path of my career.

\section{National committees}

I'm on several committees, including the NHS England clinical reference groups for rehabilitation and disability, and for major trauma and burns. Over the years I've been on a number of British Society of Rehabilitation Medicine committees but I never expected to be president, especially as I'm not an academic, and I feel so honoured that its membership elected me. 


\section{Career timeline}

1.President, British Society of Rehabilitation Medicine

2.2017 to present Clinical lead for neurorehabilitation transformation,

Greater Manchester

3.2015 to present Director, Greater Manchester Major Trauma

Rehabilitation, Greater Manchester Major Trauma Network

4.2015-2018 Chair, Royal College of Physicians Joint Specialty Committee for Rehabilitation Medicine

5.2012 to present British Society of Rehabilitation Medicine committees 6.2012-2015 Clinical lead for major trauma at Salford Royal Hospital, and Greater Manchester lead for rehabilitation following major trauma

7.2001 to present Clinical lead for neurorehabilitation, Salford Royal Hospital

8.2001 to present Hyper-Acute Neurorehabilitation Unit, Greater Manchester Neurosciences Centre, Salford Royal Hospital

9.1996 to present Consultant in neurorehabilitation and medical director for adult neurorehabilitation services, Priory Highbank Centre, Bury

101988 to present Consultant in rehabilitation medicine, Rochdale and Salford

111988-2008 Floyd Unit for Neurological Rehabilitation, Pennine Acute Hospitals NHS Trust 